\title{
PENGARUH MODEL PEMBELAJARAN CONECCTING, ORGANIZING, REFLECTING, EXTENDING (CORE) TERHADAP PEMAHAMAN KONSEP FISIKA DAN KEMAMPUAN BERPIKIR KRITIS
}

\section{THE EFFECT OF CONNECTING, ORGANIZING, REFLECTING, EXTENDING (CORE) LEARNING MODEL TOWARD UNDERSTANDING THE CONCEPTS OF PHYSICS AND THE CRITICAL THINGKING SKILL}

\author{
Murniati", Syahrial Ayub, dan Hairunisyah Sahidu \\ Program Studi Pendidikan Fisika, Jurusan Pendidikan MIPA, FKIP, Universitas Mataram, Indonesia \\ Email: atimurni300@gmail.com
}

Diterima: 22 November 2019. Disetujui: 3 Desember 2019. Dipublikasikan: 2 Maret 2020

\begin{abstract}
Abstrak. Penelitian ini bertujuan untuk mengetahui pengaruh model pembelajaran Connecting, Organizing, Reflecting, Extending (CORE) terhadap pemahaman konsep fisika dan kemampuan berpikir kritis peserta didik SMAN 1 Labuhan Haji. Jenis penelitian quasi experiment dengan desain penelitian non-equivalent control group design. Populasinya seluruh peserta didik kelas XI IPA SMAN 1 Labuhan Haji Tahun Pelajaran 2019/2020 yang berjumlah 157 orang dengan teknik pengambilan sampel purposive sampling. Terdapat dua sampel yang diambil yaitu peserta didik kelas XI IPA 3 sebagai kelas eksperimen yang diberikan perlakuan berupa model pembelajaran CORE dan peserta didik kelas XI IPA 4 sebagai kelas kontrol yang diberikan perlakukan pembelajaran konvensional. Jenis tes yang digunakan yaitu pilihan ganda sebanyak 15 item soal untuk pemahaman konsep dan soal essay sebanyak 5 item untuk kemampuan berpikir kritis. Uji hipotesis menggunakan uji MANOVA. Hasil uji hipotesis menunjukkan signifikan 0,024 sehingga $\mathrm{H}_{0}$ ditolak dan $\mathrm{H}_{\mathrm{a}}$ diterima. Kesimpulannya terdapat pengaruh model pembelajaran CORE terhadap pemahaman konsep fisika dan kemampuan berpikir kritis peserta didik SMAN 1 Labuhan Haji.
\end{abstract}

Kata kunci: Model Pembelajaran CORE, Pemahaman Konsep Fisika, Kemampuan Berpikir Kritis

\begin{abstract}
This study to determine the effect of the Connecting, Organizing, Reflecting, Extending (CORE) learning model on the understanding of physics concepts and critical thinking skills of SMAN 1 Labuhan Hajj students. This type of research is a quasi experiment with a non-equivalent control group design. The population was all students of class XI IPA SMAN 1 Labuhan Haji in the Academic Year 2019/2020, totaling 157 people with a purposive sampling technique. There are two samples taken namely students of class XI IPA 3 as an experimental class who are given treatment in the form of CORE learning models and students of class XI IPA 4 as a control class given the conventional learning treatment. The type of test used is multiple choice as many as 15 items for understanding concepts and as many as 5 items for critical thinking skills. Hypothesis testing uses the MANOVA test. Hypothesis test results showed significant 0.024 so that $\mathrm{H}_{0}$ was rejected and $\mathrm{H}_{\mathrm{a}}$ was accepted. In conclusion, there is an influence of the CORE learning model on the understanding of physics concepts and the critical thinking skills of students of SMAN 1 Labuhan Haji.
\end{abstract}

Keywords: CORE Learning Model, Understanding Physics Concepts, Critical Thinking Skills

\section{PENDAHULUAN}

Pendidikan merupakan salah satu aspek penting dan menjadi tolak ukur kemajuan suatu bangsa, karena melalui pendidikan yang baik dapat dihasilkan sumber daya manusia (SDM) yang unggul dan berkualitas. Upaya pemerintah dalam meningkatkan kualitas pembelajaran yakni salah satunya melalui penyempurnaan kurikulum. Penyempurnaan kurikulum yang dilakukan pemerintah, yakni lahirnya kurikulum 2013. Kurikulum 2013 dikembangkan untuk menyiapkan generasi masa depan yang memiliki kemampuan berkomunikasi, kemampuan berpikir jernih dan kritis [1].

Perkembangan ilmu pendidikan di Indonesia saat ini sudah mengarah pada kemampuan berpikir tingkat tinggi atau sering disebut sebagai
High Order Thinking Skill (HOTS). Kemampuan berpikir tingkat tinggi salah satunya yaitu kemampuan berpikir kritis. Mata pelajaran yang dapat mengembangkan kemampuan berpikir kritis salah satunya yaitu pelajaran fisika. Pelajaran fisika di SMA dan MA dimaksudkan sebagai sarana untuk melatih peserta didik agar dapat menguasai pengetahuan, konsep, prinsip fisika, memiliki kecakapan ilmiah, dan keterampilan berpikir kritis. Pemahaman terhadap suatu konsep sangat dibutuhkan dalam pembelajaran fisika.

Studi pendahuluan yang dilakukan saat prose pembelajaran melalui observasi dan wawancara dengan guru fisika di SMAN 1 Labuhan Haji, diperoleh beberapa permasalahan yang dihadapi pada saat proses pembelajaran fisika diantaranya adalah sebagai berikut: 1) pembelajaran 
cenderung dilaksanakan melalui pola pengajaran teori, hafalan berupa persamaan-persamaan, kemudian memberikan contoh soal dan latihan, 2) Peserta didik kurang diberikan kesempatan untuk menggali pengetahuan dan mengaitkan konsep yang dipelajari ke dalam situasi yang berbeda, 3) ketika memulai proses pembelajaran guru langsung menjelaskan konsep baru yang akan dipelajari, tanpa menghubungkan kembali konsep lama yang sudah diberikan sebelumnya, 4) hanya sebagian peserta didik yang memperhatikan ketika guru menjelaskan dan mengerjakan latihan soal yang diberikan sedangkan yang lain mengerjakan hal-hal diluar pembelajaran fisika. Dampak dari hal tersebut menyebabkan pemahaman konsep peserta didik masih rendah serta keterampilan proses yang dilandasi pada kemampuan berpikir kritis belum bisa diberdayakan.

Berns \& Erickson dalam Sakti [2], menyatakan dalam suatu domain belajar, pemahaman merupakan prasyarat mutlak untuk tingkatan kemampuan kognitif yang tinggi, aplikasi, analisis, sintesis, dan evaluasi. Pemahaman (comprehension) adalah kemampuan seseorang untuk mengerti atau memahami sesuatu setelah sesuatu itu diketahui dan diingat, sedangkan memahami merupakan mengetahui tentang sesuatu dan dapat melihatnya dari berbagai aspek. Peserta didik dikatakan memahami sesuatu apabila ia dapat memberikan penjelasan atau memberi uraian yang lebih rinci tentang hal itu dengan menggunakan kata-katanya sendiri. Anderson dan Krathwohl [3], berpendapat bahwa peserta didik dikatakan sudah memahami suatu konsep jika dapat mengkonstruksi makna dari pesan-pesan pembelajaran, baik yang bersifat lisan, tulisan ataupun grafis, yang disampaikan melalui pengajaran, buku, atau layar komputer. Bloom dalam Anderson berpendapat ada tujuh indikator yang dapat dikembangkan dalam tingkatan proses kognitif pemahaman antara lain; (1) menafsirkan; (2) mencontohkan; mengklasifikasikan; (4) merangkum; (5) menyimpulkan; (6) membandingkan; dan (7) menjelaskan. Peserta didik dikatakan memahami ketika mereka menghubungkan pengetahuan "baru" dan pengetahuan lama, atau lebih tepatnya pengetahuan baru yang masuk dipadukan dengan skema-skema dan kerangka-kerangka kognitif yang telah ada. Hal tersebut menuntut peserta didik untuk berpikir sebagai proses menentukan hubunganhubungan secara bermakna antara aspek-aspek dari suatu bagian pengetahuan [4]. Ennis dalam Puspita [5] berpendapat bahwa, berpikir kritis adalah cara berpikir reflektif yang masuk akal atau berdasarkan nalar yang difokuskan untuk menentukan apa yang harus diyakini dan dilakukan. Ennis dalam Asmawati [6] terdapat 12 indikator keterampilan berpikir kritis yang dikelompokkan dalam 5 aspek keterampilan berpikir kritis antara lain; (1) memberikan penjelasan sederhana (elementery clarification), (2) membangun keterampilan dasar (basicsupport), (3) menyimpulkan (inference), (4) membuat pejelasan lebih lanjut (advanced clarification), dan (5) strategi dan taktik (strategies and tactics)

Hal ini menuntut peserta didik harus mampu menemukan sendiri permasalahan yang harus dislesaikan sehingga pada proses pembelajaran melibatkan peserta didik harus aktif yang menjadi pusat kegiatan belajar dan pembelajaran di kelas dengan lenih menekanan kegiatan diskusi. Model CORE merupakan model pembelajaran yang menerapkan cara diskusi dapat mempengaruhi perkembangan pengetahuan dan berpikir reflektif. CORE merupakan singkatan dari empat kata yang memiliki kesatuan fungsi dalam proses pembelajaran, yaitu Connecting, Organizing, Reflecting, dan Extending. Harmsem dalam Budiyanto [7], menyatakan bahwa elemen-elemen tersebut digunakan untuk menghubungkan informasi lama dengan informasi baru, mengorganisasikan sejumlah materi yang bervariasi, merefleksikan segala sesuatu yang dipelajari, dan mengembangkan lingkungan belajar.

\section{METODE PENELITIAN}

Jenis penelitian digunakan yaitu quasi experiment (eksperimen semu) dengan desain penelitian nonequivalent control group design. Pelaksanaan penelitian diawali dengan pemberian tes awal (pretest) kepada kedua kelompok sampel. Kedua kelompok mendapatkan perlakuan yang berbeda yaitu kelompok eksperimen diberikan perlakuan berupa penerapan model pembelajaran CORE (X), sedangkan kelas kontrol diberikan perlakuan dengan menerapkan pembelajaran konvensional. Kedua kelompok sama-sama mendapatkan pengukuran dengan dilakukan tes akhir (posttest) setalah perlakuan yang diberikan (pada kelompok eksperimen) selesai. Instrumen yang digunakan berupa tes pilihan ganda dan tes essay pada materi Elastisitas dan Hukum Hooke. Subjek penelitian adalah peserta didik kelas XI IPA di SMAN 1 Labuhan Haji tahun pelajaran 2019/2020. Kelas XI IPA 3 (35 orang) sebagai kelas eksperimen dan kelas XI IPA 4 (36 orang) sebagai kelas control dengan teknik pengambilan sampel yaitu purposive sampling.

Instrumen tes pilihan ganda untuk pemahaman konsep sebanyak 5 item soal dan tes essay untuk kemampuan berpikir kritis sebanyk 5 item soal. Selain itu pula mnggunakan LKPD untuk mengukur proses kemampuan berpikir kritis peserta didik selama proses pembelajaran berlangsung untuk setiap pertemuannya. Data hasil pemahaman konsep dan kemampuan berpikir kritis diuji prasyarat berupa uji normalitas dan uji homogenitas. Kemudian dilanjutkan dengan uji hipotesis menggunakan uji MANOVA yang terdiri dari dua syarat yaitu uji Levene's dan uji Box'M. 


\section{HASIL DAN PEMBAHASAN}

Penelitian dimulai dengan memberikan perlakuan yang berbeda pada kedua kelas. Ketika diberikan perlakuan maka dilakukan penilaian pada proses kemampuan berpikir kritis kemudian diberikan tes akhir untuk menilai pemahaman konsep dan kemampuan berpikir krtitis. Berikut nilai pemahaman konsep peserta didik kelas eksperimen dan kelas kontrol yang disajikan pada Tabel 1.

Tabel 1. Hasil Tes Akhir Pemahaman Konsep

\begin{tabular}{lcc}
\hline \multicolumn{1}{c}{ Pembeda } & \multicolumn{2}{c}{ Kelas } \\
& Eksperimen & Kontrol \\
\hline Jumlah peserta didik & 35 & 35 \\
Nilai tertinggi & 86,66 & 73,33 \\
Nilai terendah & 6,66 & 20,00 \\
Rata-rata & 45,15 & 44,49 \\
\hline
\end{tabular}

Tabel 1 menunjukkan bahwa peserta didik pada kelas eksperimen memiliki nilai lebih tinggi dibandingkan kelas kontrol. Rangkaian pembelajaran yang diterapkan pada kelas eksperimen dengan menggunakan model CORE dapat meningkatkan pemahaman konsep peserta didik. Dalam menerapkan model pembelajaran CORE terdiri atas empat tahapan. Setiap tahapan dalam model CORE memegang pengaruh masingmasing. Akan tetapi, pada tahap Connecting menjadi tahap penting dalam model ini, karena mengingat pada sekolah tempat peneliti melakukan penelitian bahwa ketika guru masuk ke kelas memberikan materi baru, maka langsung ke pokok materi baru tanpa ada keterkaitan antara pengetahuan atau materi yang lama dengan yang baru, sehingga perlu adanya sedikit pengulangan pada materi sebelumnya agar pengetahuan peserta didik berkaitan dan tidak terpetakan sendiri-sendiri.

Kegiatan pembelajaran di kelas eksperimen pada pertemuan pertama diawali dengan mengajukan beberapa pertanyaan terkait tentang akibat yang diberikan oleh gaya. Guru melakukan sedikit demonstrasi yaitu menarik sebuah meja, kemudian peserta didik diminta untuk mengamati perubahan apa yang terjadi pada meja tersebut. Selain itu pula, guru memfasilitasi peserta didik berupa LKPD dan beberapa media pembelajaran seperti menyediakan beberapa benda elastis dan plastis. Tahap selanjutnya yaitu Organizing, dimana peneliti meminta peserta didik untuk melakukan diskusi terkait dengan pengaruh gaya pada bendabenda tersebut. Pada tahap ini peserta didik bertukar pendapat dan mencari atau mengumpulkan informasi dari berbagai sumber seperti buku paket dan LKS, kemudian peneliti meminta salah satu kelompok untuk mempersentasikan hasil diskusinya dan kelompok lain memperhatikan dan memberikan tanggapan. Tahap berikutnya adalah Reflecting, yaitu peserta didik diberikan kesempatan untuk memikirkan kembali informasi yang sudah didapat dan dipahaminya pada tahap diskusi atau hasil kerja kelompoknya pada tahap Organizing sudah benar atau masih terdapat kesalahan yang perlu diperbaiki kemudian menyimpulkan bersama. Selanjutnya tahap Extending, dimana peserta didik dapat memperluas pengetahuan mereka tentang apa yang sudah diperoleh selama proses belajar mengajar berlangsung. Perluasan pengetahuan dapat dilakukan dengan cara mengerjakan soal-soal yang berhubungan dengan konsep yang dipelajari tetapi dalam situasi yang baru atau konteks yang berbeda secara berkelompok.

Pembelajaran fisika mengajarkan keterkaitan antar konsep, sehingga pengetahuan yang sudah ada dalam diri peserta didik dengan pengetahuan yang akan diterima merupakan salah satu unsur yang sangat penting. Oleh karena itu, koneksi yang baik sangat dibutuhkan dalam menghubungkan pengetahuan tersebut. Peserta didik mengorganisasikan pengetahuannya dan belajar untuk mengolah pengetahuan mereka sendiri melalui diskusi kelompok. Peserta didik dapat berpartisipasi aktif untuk merefleksikan apa yang telah mereka pelajari sehingga meningkatkan proses berpikirnya, membangun pengetahuan baru, dan dapat memperluas pengetahuan mereka tentang materi yang telah dipelajari.

Berikut nilai kemampuan berpikir kritis peserta didik kelas eksperimen kelas control yang disajikan pada Tabel 2.

Tabel 2. Hasil Tes Akhir Kemampuan Berpikir Kritis

\begin{tabular}{lcc}
\hline \multicolumn{1}{c}{ Pembeda } & \multicolumn{2}{c}{ Kelas } \\
& Eksperimen & Kontrol \\
\hline Jumlah peserta didik & 35 & 35 \\
Nilai tertinggi & 85,00 & 10,00 \\
Nilai terendah & 75,00 & 5,00 \\
Rata-rata & 52,00 & 41,57 \\
\hline
\end{tabular}

Kemampuan berpikir kritis diukur pada saat proses pembelajaran dan tes akhir. Kemampuan berpikir kritis pada saat proses pembelajaran dilihat dari awal kegiatan pembelajaran saat peneliti mengajukan pertanyaan hingga peserta didik melakukan diskusi kelompok. Kemampuan berpikir kritis peserta didik selama prsoes pembelajaran masih dalam kategori kurang kritis tetapi terdapat peningkatan disetiap pertemuan. Penyebab masih rendahnya kemampuan berpikir kritis peserta didik selama proses pembelajaran yaitu ketika pembelajaran masih ada campur tangan guru. Guru banyak membantu peserta didik dalam menjawab soal latihan hingga menarik kesimpulan khususnya pada kelas kontrol. Kelas eksperimen mengalami peningkatan kemampuan berpikir kritis yang lebih 
tinggi dibandingkan kelas kontrol untuk setiap pertemuan.

Hasil yang diperoleh ketika diberikan tes awal (pretest) yaitu kelas eksperimen dan kelas kontrol memiliki nilai tertinggi dan nilai terendah yang sama, tetapi nilai rata-rata kemampuan berpikir kritis untuk kelas eksperimen lebih tinggi daripada kelas kontrol. Indikator kemampuan berpikir kritis yang paling tinggi yaitu membuat penjelasan lebih lanjut dan yang terendah yaitu strategi dan taktik untuk kelas kontrol dan kelas eksperimen. Rata-rata kemampuan berpikir kritis peserta didik di kelas eksperimen dan kelas kontrol dapat dikategorikan kurang kritis berdasarkan pedoman kategori kemampuan berpikir kritis Yuliati [8]. Dapat dikatakan bahwa pembelajaran yang diterapkan sebelumnya kurang menekankan pada kemampuan berpikir kritis peserta didik. Penyebab rendahnya kemampuan berpikir kritis pada kedua kelas juga disebabkan karena kedua kelas belum mempelajari materi Elastisitas dan Hukum Hooke.

Pembelajaran menggunakan model pembelajaran CORE dapat meningkatkan kemampuan berpikir kritis peserta didik. Tahap Connecting menuntut peserta didik mengembangkan kemampuan berpikir kritisnya ketika pengajar meminta peserta didik menjawab pertanyaan yang diajukan untuk mengingat kembali materi sebelumnya, khususnya indikator memberikan penjelasan sederhana. Indikator membangun keterampilan dasar dapat dilihat ketika melakukan percobaan dan mengumpulkan informasi dari sumber lain seperti buku untuk menyelesaikan permasalahan yang dirumuskan pada tahap Organizing. Tahap ketiga yaitu Reflecting, peneliti memberikan kesempatan kepada peserta didik untuk memikirkan kembali terkait dengan permasalahan yang didiskusikan dan peserta didik menjawab pertanyaan yang diajukan sehingga kemampuan berpikir kritis khususnya penjelasan lebih lanjut dapat ditingkatkan. Selain itu pada tahap ini juga peserta didik diminta menarik kesimpulan untuk menjawab permasalahan yang telah didiskusikan pada awal pembelajaran, pada tahap ini indikator menyimpulkan dapat ditingkatkan. Pada tahap Extending, peserta didik diminta untuk menyelesaikan soal-soal yang dapat memperluas pengetahuan mereka sehingga dapat meningkatkan strategi dan taktik dalam menyelesaikan soal tersebut.

Tes akhir (posttest) diberikan pada kelas eksperimen dan kelas kontrol untuk mengetahui apakah ada pengaruh atas perlakuan yang sudah diberikan untuk materi Elastisitas dan Hukum Hooke. Tes akhir (posttest) yang diberikan jumlah dan bobot soalnya sama dengan tes awal (pretest). Hasil yang diperoleh setelah diberikan tes akhir (posttest) yaitu nilai tertinggi nilai terendah kelas eksperimen lebih tinggi dibandingkan kelas kontrol. Nilai rata-rata kemampuan berpikir kritis kelas eksperimen lebih tinggi dibandingkan kelas kontrol namun masih dikategorikan kurang kritis. Penyebab kelas eksperimen dan kelas kontrol masih kurang kritis adalah penerapan model pembelajaran masih tergolong singkat yaitu hanya 3 kali pertemuan. Untuk meningkatkan kemampuan berpikir kritis peserta didik menjadi sangat kritis diperlukan penerapan model pembelajaran CORE dalam jangka waktu yang lama.

Uji prasyarat juga diberlakukan untuk tes akhir dimana hasil uji homogenitas tes akhir kedua kelas sampel adalah homogen, begitupula dengan uji normalitas, kedua kelas sampel dinyatakan terdistribusi normal, karena hasil uji prasyarat tes awal maupun tes akhir kedua kelas sampel termasuk kategori homogen dan terdistribusi normal, maka dapat dilanjutkan untuk menguji hipotesis. Uji hipotesis menggunakan uji MANOVA yaitu untuk mengetahui pengaruh model pembelajaran CORE terhadap pemahaman konsep fisika dan kemampuan berpikir kritis secara bersama-sama. Uji MANOVA memiliki dua syarat yaitu uji Levene's dan uji Box'M. Data yang digunakan dalam uji hipotesis yaitu data tes akhir (posttest). Nilai signifikan yang didapatkan pada saat uji box dan uji levene's lebih besar dari 0,05 sehingga uji MANOVA dapat dilanjutkan. Berdasarkan uji MANOVA yang telah dilakukan, didapatkan signifikannya sebesar 0,024 yang artinya lebih kecil dari 0,05 sehingga dapat disimpulkan bahwa ada pengaruh model pembelajaran CORE terhadap pemahaman konsep dan kemampuan berpikir kritis peserta didik.

Hasil yang diperoleh sesuai dengan penelitian sebelumnya yaitu Ambarsih [9] yang menyatakan bahwa model pembelajaran CORE dapat mengembangkan kemampuan berpikir kritis dan mengaktifkan peserta didik dimana skor keterampilan berpikir kritis dalam pembelajaran IPA pada peserta didik yang mengikuti pembelajaran dengan model CORE cenderung tinggi, dengan mean 25,64 $(64,10 \%)$ daripada skor keterampilan berpikir kritis dalam pembelajaran IPA pada peserta didik yang mengikuti pembelajaran model konvensional cenderung rendah dengan mean 16,52 (41,30\%). Model ini juga telah diaplikasikan oleh Mailisa [10] pada materi getaran harmonis yang menyatakan bahwa model pembelajaran CORE mempengaruhi kompetensi pengetahuan fisika peserta didik. Hal ini ditunjukkan dari perbandingan nilai rata-rata kompetensi pengetahuan fisika untuk kelas eksperimen lebih bagus dibandingkan dengan kelas kontrol. Pada kompetensi pengetahuan, untuk kelas eksperimen didapatkan nilai rata-rata kelasnya 80,97 sedangkan untuk kelas kontrol didapatkan nilai ratarata kelasnya 72,26. Hal ini sejalan dengan penelitian yang dilakukan Humaira [11] peserta didik yang belajar dengan menggunakan model pembelajaran CORE lebih baik daripada kemampuan komunikasi matematis siswa yang 
belajar dengan pembelajaran konvensional. Hal ini juga dapat dilihat dari skala rata-rata kemampuan komunikasi matematis peserta didik setiap indikator serta nilai rata-rata tes hasil belajar matematika peserta didik yang belajar matematika dengan model CORE lebih baik daripada peserta didik yang belajar dengan pembelajaran konvensional. Dalam pembelajaran matematika dengan menerapkan model CORE dapat meningkatkan kemampuan koneksi matematis peserta didik [12]. Hal ini terjadi dikarenakan dengan menggunakan model CORE, peserta didik dapat melatih daya ingat serta daya pikir kritis sehingga wawasan dan pandangan peserta didik akan lebih berkembang dalam menyelesaikan permasalahan yang berkaitan dengan materi matematika ataupun matematika dengan disiplin ilmu lainnya. Beladina [13] dalam penelitiannya mengungkapkan kreativitas matematis peserta didik kelas eksperimen yang menerapkan model pembelajaran CORE berbantuan LKPD lebih baik daripada kreativitas matematis peserta didik pada kelas kontrol yang menerapkan model pembelajaran konvensional, hal ini karena pembelajaran yang menerapkan model pembelajaran CORE berbantuan LKPD dapat membuat peserta didik lebih aktif dalam belajar untuk mengkonstruksi pengetahuannya sendiri dengan cara berdiskusi dalam kelompoknya masingmasing melalui kegiatan connecting, organizing, reflecting, dan extending [14]. Penelitian-penelitian di atas banyak terkait pada mata pelajaran matematika. Namun, matematika sangat erat kaitannya dengan fisika karena karakteristik mata pelajaran matematika hampir mirip dengan fisika, teori fisika banyak dinyatakan dalam notasi matematis, selain itu rumus matematika juga merupakan induk dari rumus fisika.

Berdasarkan teori dan temuan dalam penelitian ini dapat dinyatakan bahwa model pembelajaran CORE mampu membantu peserta didik dalam memahami konsep fisika dan meningkatkan kemampuan berpikir kritis baik teori maupun penerapannya dalam kehidupan sehari-hari, hal ini karena model pembelajaran CORE dapat menjadikan peserta didik lebih aktif dalam belajar, terbukti pada saat proses pembelajaran rasa ingin tahu peserta didik lebih tinggi karena untuk dapat berperan aktif, maka peserta didik harus dapat mengingat informasi dan menggunakan pengetahuannya untuk menghubungkan topik yang didiskusikan. Selain itu, model pembelajaran CORE juga dapat melatih daya ingat peserta didik tentang suatu konsep/informasi, dimana peserta didik mengatur dan mengorganisasikan informasi dari berbagai sumber menjadi suatu pengetahuan baru baik dengan cara meringkas hasil-hasil penting dalam diskusi atau menuliskan langkah-langkah yang menghubungkan antara pengetahuan lama dengan pengetahuan baru yang mereka diskusikan. Peserta didik juga dilatih untuk berpikir reflektif baik sebelum maupun sesudah diskusi agar peserta didik mampu menyelesaikan masalah berbeda namun memiliki dasar konsep yang sama menggunakan pengetahuan lama dan pengetahuan baru yang dimiliki, serta memberikan peserta didik pembelajaran yang bermakna. Kegiatan diskusi untuk memperoleh berbagai macam informasi dari teman-teman dan gurunya sesuai topik serta mencoba untuk menjelaskan kembali kepada temanteman dan guru.

Kendala-kendala yang dialami oleh peneliti khususnya saat melaksanakan pembelajaran di sekolah ialah kurang optimalnya dalam pembimbingan kelompok diskusi peserta didik dan pengelolaan waktu, karena model pembelajaran CORE ini membutuhkan persiapan yang optimal dari guru serta memerlukan banyak waktu, dan juga tidak semua materi pelajaran dapat menggunakan model CORE. Kendala lainnya yaitu tidak terbiasanya peserta didik dalam mengerjakan soal-soal yang menuntut peserta didik mengemukakan suatu alasan. Peserta didik mengalami kesulitan untuk memberikan alasan terkait jawaban yang dipilih. Hal ini menyebabkan skor peserta didik berkurang akibat alasan yang diberikan peserta didik kurang tepat dan kekurangan waktu untuk menjawab.

\section{KESIMPULAN}

Berdasarkan hasil penelitian dan pembahasan dapat disimpulkan bahwa terdapat pengaruh model pembelajaran CORE terhadap pemahaman konsep fisika dan kemampuan berpikir kritis peserta didik kelas XI di SMAN 1 Labuhan Haji tahun pelajaran 2019/2020. Model CORE ini dapat dijadikan sebagai salah satu alternatif variasi model pembelajaran dalam mata pelajaran fisika, diperlukan managemen organisasi kelas agar waktu pembelajaran lebih efektif guna menyelesaikan bahan diskusi dan untuk menunjang pembelajaran lebih bermakna, memfasilitasi peserta didik berupa beberapa media pembelajaran akan sangat membantu dalam memahami fisika.

\section{DAFTAR PUSTAKA}

[1] Daryanto, \& Sudjendro, P. 2014. Siap Menyongsong Kurikulum 2013. Yogyakarta: Gava Media.

[2] Sakti, I., Yuniar M. P., \& Risdianto, E. 2012. Pengaruh Model Pembelajaran Langsung (Direct Instruction) Melalui Media Animasi Berbasis Macromedia Flash Terhadap Minat Belajar Dan Pemahaman Konsep Fisika Siswa Di SMA Plus Negeri 7 Kota Bengkulu. EXACTA, 10(1), 1-10.

[3] Anderson, L. W. \& Krathwohl, D. R. 2015. Kerangka Landasan untuk Pembelajaran, Pengajaran, dan Asesmen. Yogyakarta: Pustaka Pelajar. 
[4] Sagala, S. 2013. Konsep dan Makna Pembelajaran: untuk Membantu Memecahkan Problematika Belajar dan Mengajar. Bandung: CV Alfabeta.

[5] Puspita, A. T., \& Jatmiko, B. 2013. Implementasi Model Pembelajaran Inkuiri Terbimbing (Guided Inquiry) terhadap Keterampilan Berpikir Kritis Siswa pada Pembelajaran Fisika Materi Fluida Statis Kelas XI di SMA Negeri 2 Sidoarjo. Inovasi Pendidikan Fisika, 2(3).

[6] Asmawati, E. Y. 2015. Lembar Kerja Siswa (LKS) Menggunakan Model Guided Inquiry untuk Meningkatkan Keterampilan Berpikir Kritis dan Penguasaan Konsep Siswa.Jurnal Pendidikan Fisika, 3(1).

[7] Budiyanto, M.A.K. 2016. Sintaks 45 Metode Pembelajaran dalam Student Centered Learning (SCL). Malang: UMM Press.

[8] Yuliati, D.I., Yulianti, D., \& Khanafiyah, S. 2011. Pembelajaran Fisika Berbasis Hands On Activities untuk Menumbuhkan Kemampuan Berpikir Kritis dan Meningkatkan Hasil Belajar Siswa SMP. Jurnal Pendidikan Fisika Indonesia Vol. 7, 23-27.

[9] Ambarsih, H. U. 2016. Meningkatkan Kemampuan Berpikir Kritis Siswa pada Materi Gaya Gesek Melalui Model Pembelajaran CORE (Connecting, Organizing, Reflecting, and Extending). Prosiding Seminar Nasional Quantum, ISSN: 2477-1511.

[10] Mailisa, P., Masril, M., \& Darvina, Y. 2017. Pengaruh Penerapan Bahan Ajar Terintegrasi Nilai-Nilai Karakter dalam Model Pembelajaran Kooperatif Tipe CORE pada Materi Usaha Energi dan Getaran Harmonis Sederhana Terhadap Kompetensi Siswa Kelas XI SMAN 1 TARUSAN. Pillar Of Physics Education, 9(1).

[11]Humaira, F. 2014. Penerapan Model Pembelajaran CORE pada Pembelajaran Matematika Siswa Kelas X SMAN 9 Padang. Jurnal Pendidikan Matematika, 3(1).

[12] Prasetyo, T. I., \& Syaban, M. 2018. Pengaruh Penerapan Model Pembelajaran Connecting, Organizing, Reflecting, Extending (CORE) terhadap Peningkatan Kemampuan Koneksi Matematis Siswa SMA. INTERMATHZO. Jurnal Pendidikan dan Pembelajaran Matematika, 3(1), 19-27.

[13] Beladina, N., Suyitno, A., \& Kusni. 2013. Keefektifan Model Pembelajaran CORE Berbantuan LKPD terhadap Kreativitas Matematika Siswa. Unnes Journal of Mathematics Education, II (3): 3439.

[14] Mukarramah, M., Verawati, N. N. S. P., \& Harjono, A. (2019). Pengaruh Model Pembelajaran Core Terhadap Penguasaan Konsep Fisika Peserta Didik Kelas XI MAN
Lombok Barat. Jurnal Pijar Mipa, 14(3), 176183. 